\title{
Occurrence of Shiga-toxigenic Escherichia coli in Stomoxys calcitrans (Diptera: Muscidae)
}

Ocorrência de Escherichia coli Shiga-Toxigênica em Stomoxys calcitrans (Diptera: Muscidae)

Bruno Gomes de Castro ${ }^{1 *}$; Miliane Moreira Soares de Souza ${ }^{2}$; Adriana Hamond Regua-Mangia ${ }^{3}$; Avelino José Bittencourt ${ }^{2}$

${ }^{1}$ Instituto de Ciências da Saúde, Universidade Federal de Mato Grosso - UFMT, Sinop, MT, Brasil

${ }^{2}$ Instituto de Veterinária, Universidade Federal Rural do Rio de Janeiro - UFRRJ, Seropédica, RJ, Brasil

${ }^{3}$ Departamento de Ciências Biológicas - DCB, Escola Nacional de Saúde Pública Sérgio Arouca - Ensp,

Fundação Instituto Oswaldo Cruz - Fiocruz, Rio de Janeiro, RJ, Brasil

Received December 17, 2012

Accepted May 17, 2013

\begin{abstract}
This study aimed to verify the occurrence of Shiga toxin-producing Escherichia coli (STEC) strains in three distinct anatomic parts of the stable fly Stomoxys calcitrans by multiplex polymerase chain reaction (PCR Multiplex). According to the results obtained, E. coli was identified in $19.5 \%$ of the stable flies. Shiga toxin genes were detected in $13 \%$ of the E. coli isolated, most frequently from the surface, followed by abdominal digestive tract and mouth apparatus of insects, respectively. This is the first study to detect presence of STEC in Stomoxys calcitrans in Brazil; it has also revealed the potential role of stable flies as carriers of pathogenic bacterial agents.
\end{abstract}

Keywords: Stomoxys calcitrans, Shiga toxin-producing Escherichia coli, Multiplex-PCR.

\section{Resumo}

Este estudo teve por objetivo avaliar a ocorrência de Escherichia coli Shiga-Toxigênica (STEC) em três diferentes partes anatômicas da mosca dos estábulos pela Reação de Polimerase em Cadeia Multiplex (PCR Multiplex). De acordo com os resultados obtidos, foi identificada E. coli em 19,5\% das moscas dos estábulos colhidas. Foram detectados genes de produção de Shiga toxina em 13,63\% das Escherichia coli isoladas, sendo mais frequente a superfície externa, seguido pelo trato digestivo abdominal e pelo aparelho bucal, respectivamente. Este foi o primeiro estudo no Brasil que detectou a presença de STEC em Stomoxys calcitrans e revelou o potencial papel da mosca dos estábulos em carrear um agente bacteriano patogênico.

Palavras-chave: Stomoxys calcitrans, Escherichia coli Shiga Toxigênica, Multiplex-PCR.

\section{Introduction}

Muscidae species such as the stable fly, Stomoxys calcitrans, stands out among the main insects that disperse infectious agents to farm animals. Besides using cattle feces and secretions for food and reproduction during its life phases, this fly takes blood meals from various animals. It can thus spread a number of infectious agents such as parasitic forms of helminths, protozoa, fungi and bacteria. Parasitism by this fly has specifically been associated with the outbreak of ailments among cattle (GRACZYK et al., 2001; BITTENCOURT; CASTRO, 2004).

Among the infectious agents carried by stable flies, enterobacteria have attracted attention because of their bio-reproductive

*Corresponding author: Bruno Gomes de Castro

Instituto de Ciências da Saúde, Universidade Federal de Mato Grosso - UFMT,

Av. Alexandre Ferronato, 1200B, Setor Industrial,

CEP 78557-270, Sinop, MT, Brasil

e-mail: castrobg@ufmt.br characteristics. Therefore, although Escherichia coli is part of the indigenous microbiota of the intestinal tract of nearly all mammals, some strains, such as Shiga-toxigenic E. coli (STEC), can cause diseases in a great number of animals. STEC belongs to the Enterohemorrhagic group of E. coli ('EHEC') and have been described as being etiological agents of human illnesses, ranging from mild gastroenteritis to serious infections as hemorrhagic colitis and hemolytic uremic syndrome (KARMALI, 1989; GRIFFIN; TAUXE, 1991).

The natural reservoirs of STEC are domesticated and wild ruminants, mainly cattle, which disperse this agent through their feces (CAPRIOLI et al., 2005). Cattle do not usually present any clinical symptoms. Furthermore, products from these animals, such as milk and meat, are also potential sources of this agent, mainly when these products are eaten without proper heat treatment, 
as pasteurization or cooking (LIRA et al., 2004; HUSSEIN; SAKUMA, 2005).

Information about the occurrence and genetic-epidemiological aspects of these microorganisms in Brazil is still limited. Strains producing Shiga toxin, codified by the stx gene, have been isolated from apparently healthy cattle (CERQUEIRA et al. 1999; FARAH et al., 2007), with high prevalence of this strain and apparent predominance of non-O157 STEC (CERQUEIRA et al. 1999; IRINO et al. 2005; PIGATTO et al., 2008).

Flies of the Muscidae family play an important role in disseminating STEC and other strains of E. coli with high pathogenic potential (IWASA et al., 1999; AHMAD et al., 2007; TALLEY et al., 2009).

Therefore, the aim of this study was to evaluate the capacity of stable flies, collected on dairy farms in the state of Rio de Janeiro, Brazil, to carry STEC on/in three different structures: body surface, mouthparts and abdominal digestive tract.

\section{Materials and Methods}

In this study, we visited 10 dairy farms in the state of Rio de Janeiro, Brazil. On each farm, 20 specimens of Stomoxys calcitrans flying around the cattle were captured, placed in sterile glass tubes and kept under refrigeration until further use.

Briefly, for laboratory procedures, the captured flies were identified according to Furman and Catts (1982), and only the $S$. calcitrans specimens were killed by freezing at $-10{ }^{\circ} \mathrm{C}$. Each frozen fly was placed in a tube containing enriched brain-heart infusion (BHI) broth, agitated in this medium and transferred to another tube containing $70 \%$ alcohol for 2 minutes as described by Hillerton and Bramley (1985). Following the sterilization step of the outer surface, each fly was put on its back on a sterile Petri dish and a stereoscopic microscope was used to aid removal of the mouth apparatus and abdominal digestive tract, as described by Castro et al. (2007). The anatomic segments were macerated in BHI broth and incubated in bacteriological chamber at $37^{\circ} \mathrm{C}$ for 24 hours.

After the incubation period, the samples were transferred to Petri dishes containing MacConkey agar and Eosin Methyl Blue (EMB) agar culture media. Colonies were selected according to their morphophysiological characteristics and submitted to preliminary bacterial identification assays: Gram staining, for observation of morphological and staining characteristics; and hydrolysis test with 3\% $\mathrm{KOH}$, to confirm the Gram catalysis test results. For identification of bacterial species, the following tests were conducted: behavior in triple sugar iron agar; behavior in SIM agar; production of acids by glycosis; sugar fermentation; Voges Proskauer (VP) test; methyl red (MR) test; nitrate reduction; galatinase production; citrate and malonate degradation; and other differential tests according to the microorganism involved (KONEMAN et al., 2008).

After isolation and identification of E. coli, bacterial samples were submitted to detection of the stx 1 , stx 2 and eae genes, which was performed by multiplex PCR reactions according to previous recommendations. Bacterial DNA extraction, amplification conditions and electrophoresis procedures were carried out according to the methodology proposed by China et al. (1996) with some modifications. The E. coli samples were seeded in $5 \mathrm{~mL}$ of Müeller Hinton broth (Merck) at $37^{\circ} \mathrm{C}$ for 18 to 24 hours. After the incubation period, $300 \mu \mathrm{L}$ of the culture was centrifuged for 30 seconds in a micro-centrifuge and the supernatant was discarded. The sediment was resuspended in $50 \mathrm{~mL}$ of sterile distilled water and boiled for 10 minutes, after that, the bacterial lysate was centrifuged for 30 seconds and the supernatant was used as DNA source.

Amplification assays were performed in $50 \mathrm{~mL}$ reaction volumes containing $1 \mathrm{U}$ of Taq polymerase (Fermentas, Burlington, Canada), $5 \mathrm{~mL}$ of $2 \mathrm{mM}$ deoxyribonucleoside triphosphate - dNTP (ABgene, Epsom, UK), $5 \mathrm{~mL}$ of $10 \mathrm{X}$ buffer (100 mM Tris- $\mathrm{HCl}$ [pH 8.8], $15 \mathrm{mM} \mathrm{MgCl}$, $500 \mathrm{mM} \mathrm{KCl}, 1 \%$ Triton X-100) (Fermentas, Burlington, Canada), $0.5 \mathrm{~mL}$ of each primer ( $40 \mathrm{mM}$ ) (Bioneer, Seul, South Korea); $5 \mathrm{~mL}$ of DNA were used. The reactions were carried out in an Eppendorf Master Cycler programmed to $94^{\circ} \mathrm{C}$ for 5 minutes, followed by 30 cycles at $94^{\circ} \mathrm{C}$ for 30 seconds, $50{ }^{\circ} \mathrm{C}$ for 30 seconds and $72{ }^{\circ} \mathrm{C}$ for 30 seconds. Assessment of the amplification efficiency and reproducibility of reactions were carried out under optimized conditions and performed in different assays.

Each PCR analysis included positive DNA controls E. coli $\mathrm{E} 40705$ (stx1 and eae positive) and E30121 (stx2 and eae positive) and a non-template control. Amplification reactions for the eae, stx 1 and stx 2 genes yielded DNA fragments of 570, 388 and $807 \mathrm{bp}$, respectively, which were analyzed after electrophoresis on $2.0 \%$ $\mathrm{w} / \mathrm{v}$ agarose gels run for $3 \mathrm{hs}$ at $80 \mathrm{~V}$ in $1 \mathrm{X}$ Tris-borate buffer $(10 \mathrm{X}$, Tris $1 \mathrm{M}$, Boric Acid 1M, EDTA 0.01M, pH 8.0) and stained with ethidium bromide $(0.5 \mathrm{mg} / \mathrm{mL})$. A 100bp ladder (Invitrogen Brasil) was used as DNA molecular weight marker. Genetic profiles were visualized in an ultraviolet transilluminator and documented with the UVI Pro program (UVITEC, Cambridge, UK).

\section{Results and Discussion}

Isolation and identification of colonies showed a total of 159 bacterial agents in the three parts of the 200 flies collected. The majority $(44,27.7 \%)$ was identified as E. coli. This result coincides with those of earlier studies on stable flies, which revealed a greater prevalence of $E$. coli compared to the remaining enterobacteria isolated (MORAES et al., 2004; CASTRO et al., 2007).

In the present study, $52.3 \%$ of the E. coli samples identified were isolated from the body surface, $31.8 \%$ from the mouthparts and $15.9 \%$ from the abdominal digestive tract of the flies analyzed. According to the results, E. coli strains were isolated in $19.5 \%$ of the stable flies. This is possibly explained by the usual occurrence of this microorganism in environments where feces are deposited and decomposing food is located near feed troughs, where all the developmental phases of the fly are present.

The highest prevalence of isolates observed on the body surface shows the great capacity of flies to carry bacteria on their body or secretions, as reported by Nazni et al. (2005). Moreover, identification of $E$. coli in both the mouth apparatus and abdominal digestive tract confirms the potential of this fly to act as a vector of $E$. coli in the environment, especially considering its ability to fly long distances (BAILEY et al., 1973). 
According to Rochon et al. (2004, 2005), E. coli seems to play an important role in the development of the non-parasitic phases of the stable fly. The authors reported that in experiments with laboratory-reared stable flies, a greater number of adult flies emerged from entomological cages containing media enriched with E. coli than from cages with no enriched media. The authors also reported that the newly emerged flies hold living $E$. coli bacteria in their digestive tube, so that $E$. coli is part of the microbiota of the immature forms of the stable fly, favoring their development. This observation highlights the role of flies in spreading E. coli to the environment.

After the initial laboratory process of isolation and identification, all the $E$. coli isolates were submitted to multiplex chain polymerase reaction (Multiplex-PCR) to detect the stx 1, stx2 and eae genes. Of the $44 E$. coli samples isolated from the stable flies collected, 6 contained genes characteristic of the STEC pathotype.

Of all the STEC isolated from S. calcitrans, one sample carried only the stxlgene; four carried both the stx 1 and stx 2 genes; and only one was positive for the three genes investigated: $\operatorname{stx} 1$, stx2 and eae.

Among the six E. coli strains carrying virulence genes, three came from the body surface, two from the intestinal content and one from the mouth apparatus of the stable flies. Considering that from all these three anatomical parts, particularly from the body surface, viable bacterial cells were isolated; it is assumed that these stable flies can spread STEC from all three parts evaluated. Keen et al. (2006) previously reported presence of STEC in some muscid flies, including $S$. calcitrans. However, the present findings are the first showing the capacity of this fly to disseminate STEC in Brazil.

According to the results, most of the samples investigated carried the st 22 gene, a fact that indicates the need for increased epidemiological vigilance and public health surveillance because of its high pathogenic potential for humans, as also described by Aktories and Just (2000).

Stable flies can contaminate both human and animal food with this agent, because this fly species utilizes organic compounds for oviposition and stalls and feeding troughs as resting places, where it usually defecates.

Another noteworthy observation in this study was the presence of STEC in the mouth apparatus of the flies collected. Such findings reveal the potential risk to spread this agent while flies take blood meals, allowing the contamination of animals and humans with bacteria at the time of inserting the proboscide or when regurgitating during feeding.

The stable fly normally uses substrates with high potential to shelter bacterial agents with pathogenic capacity (CASTRO et al., 2008). Therefore, further studies on this fly are important to shed light on the impact of parasitism on livestock and public health.

These results show the importance of the stable fly as a carrier of microorganisms with recognized high pathogenic potential. Greater attention should thus be focused on its control in order to prevent $E$. coli transmission, which can cause diarrheal disease and severe clinical syndromes characterized by hemolytic anemia, thrombocytopenia, and renal insufficiency, with high risk of human death, especially for those who work or live near stables.

\section{References}

Ahmad A, Nagaraja TG, Zurek L. Transmission of Escherichia coli O157:H7 to cattle by house flies. Prev Vet Med 2007; 80(1): 74-81. PMid:17306389. http://dx.doi.org/10.1016/j.prevetmed.2007.01.006

Aktories K, Just F. Bacterial Protein Toxins. Springer; 2000. 7000 p.

Bailey DL, Whitfield TL, Smittle BJ. Flight and dispersal of stable fly. J Econ Entomol 1973; 66(2): 410-411.

Bittencourt AJ, Castro BG. Stomoxys calcitrans Parasitism Associated with Cattle Diseases in Espírito Santo do Pinhal, São Paulo, Brazil. Ann NY Acad Sci 2004; 1026(1): 219-221. PMid:15604496. http://dx.doi. org/10.1196/annals.1307.033

Caprioli A, Morabito S, Brugère H, Oswald E. Enterohaemorrhagic Escherichia coli: emerging issues on virulence and modes of transmission. Vet Res 2005; 36(3): 289-311. PMid:15845227. http://dx.doi. org/10.1051/vetres:2005002

Castro BG, Souza MMS, Bittencourt AJ. Aerobic Bacterial Microbiota in Stomoxys calcitrans: Preliminary Studies in Brazil. Rev Bras Parasitol Vet 2007; 16(4): 193-197. PMid:18373894.

Castro BG, Souza MMS, Bittencourt AJ. Isolamento de espécies enterobacterianas em Stomoxys calcitrans. Cienc Rural 2008; 38(9): 2654-2657. http://dx.doi.org/10.1590/S010384782008005000024

Cerqueira AMF, Guth BEC, Joaquim RM, Andrade JRC. High occurrence of Shiga toxin-producing Escherichia coli (STEC) in healthy cattle in Rio de Janeiro State, Brazil. Vet Microbiol 1999; 70(1-2): 111-121. http:// dx.doi.org/10.1016/S0378-1135(99)00123-6

China B, Pirson V, Mainil J. Typing of bovine attaching and effacing Escherichia coli by multiplex in vitro amplification of virulence-associated genes. Appl Environ Microbiol 1996; 62(9): 3462-3465. PMid:8795238 PMCid:168144.

Farah SMSS, Souza EM, Pedrosa FO, Irino K, Silva LR, Rigo LU, et al. Phenotypic and genotypic traits of Shiga toxin-producing Escherichia coli strains isolated from beef cattle from Paraná State, southern Brazil. Lett Appl Microbiol 2007; 44(6): 607-612. PMid:17576221. http://dx.doi. org/10.1111/j.1472-765X.2007.02123.x

Furman DP, Catts EP. Manual of Medical Entomology. 4th ed. Cambridge: Cambridge University Press; 1982. 207 p.

Graczyk TK, Knight R, Gilman RH, Cranfield MR. The role of non-biting flies in the epidemiology of human infectious diseases. Microbes Infect 2001; 3(3): 231-235. http://dx.doi.org/10.1016/S12864579(01)01371-5

Griffin PM, Tauxe RV. The epidemiology of infections caused by Escherichia coli $\mathrm{O} 157: \mathrm{H} 7$, other enterohemorrhagic E. coli, and the associated hemolytic uremic syndrome. Epidemiol Rev 1991; 13(1): 60-98. PMid: 1765120

Hillerton JE, Bramley AJ. Carriage of Corynebacterium pyogenes by cattle nuisance flies Hydrotaea irritans (Fallén) and Musca autumnalis (De Geer). Vet Parasitol 1985; 18(3): 223-228. http://dx.doi.org/10.1016/03044017(85)90047-0

Hussein HS, Sakuma T. Prevalence of Shiga toxin-producing Escherichia coli in dairy cattle and their products. J Dairy Sci 2005; 88(2): 450-465. http://dx.doi.org/10.3168/jds.S0022-0302(05)72706-5

Irino K, Kato MAMF, Vaz TMI, Ramos II, Souza MAC, Cruz AS, et al. Serotypes and virulence markers of Shiga toxin-producing Escherichia 
coli (STEC) isolated from dairy cattle in São Paulo State, Brazil. Vet Microbiol 2005; 105(1): 29-36. PMid:15607081. http://dx.doi. org/10.1016/j.vetmic.2004.08.007

Iwasa M, Makino SI, Asakura H, Kobori H, Morimoto Y. Detection of Escherichia coli O157:H7 from Musca domestica (Diptera: Muscidae) at a cattle farm in Japan. J Med Entomol 1999; 36(1): 108-112. PMid:10071501.

Karmali MA. Infection by verocytotoxin-producing Escherichia coli. Clin Microbiol Rev 1989; 2(1): 15-38. PMid:2644022 PMCid:358098.

Keen JE, Wittum TE, Dunn JR, Bono JL, Durso LM. Shiga-toxigenic Escherichia coli O157 in Agricultural Fair Livestock, United States. Emerg Infect Dis 2006; 12(5): 780-786. PMid:16704838 PMCid:3293435. http://dx.doi.org/10.3201/eid1205.050984

Koneman EW, Janda SD, Schreckenberger WM, Winn JR PC. Diagnóstico Microbiológico. 6. ed. Rio de Janeiro: MEDSI; 2008. 1465 p.

Lira WM, Macedo C, Marin JM. The incidence of Shiga toxinproducing Escherichia coli in cattle with mastitis in Brazil. J Appl Microbiol 2004; 97(4): 861-866. PMid:15357736. http://dx.doi. org/10.1111/j.1365-2672.2004.02384.x

Moraes APR, Badini PV, Souza MMS, Bittencourt AJ. Avaliação da capacidade de Stomoxys calcitrans (Linnaeus, 1758) em carrear bactérias envolvidas nas etiologias das mastites de municípios do Rio de Janeiro. Rev Bras Parasitol Vet 2004; 13(4): 143-149.

Nazni WA, Seleena B, Lee HL, Jeffery J, T Rogayah TAR, Sofian MA. Bacteria fauna from the house fly, Musca domestica (L.). Trop Biomed 2005; 22(2): 225-231. PMid:16883292.

Pigatto CP, Schocken-Iturrino RP, Souza EM, Pedrosa FO, Comarella $\mathrm{L}$, Irino $\mathrm{K}$, et al. Virulence properties and antimicrobial susceptibility of Shiga toxin-producing Escherichia coli strains isolated from healthy cattle from Paraná State, Brazil. Can J Microbiol 2008; 54(7): 588-593. PMid:18641705. http://dx.doi.org/10.1139/W08-046

Rochon K, Lysyk TJ, Selinger LB. Retention of Escherichia coli by house fly and stable fly (Diptera: Muscidae) during pupal metamorphosis and eclosion. J Med Entomol 2005; 42(3): 397-403. http://dx.doi. org/10.1603/0022-2585(2005)042[0397:ROECBH]2.0.CO;2

Rochon K, Lysyk TJ, Selinger LB. Persistence of Escherichia coli in immature house fly and stable fly (Diptera: Muscidae) in relation to larval growth and survival. J Med Entomol2004; 41(6): 1082-1089. PMid:15605648. http://dx.doi.org/10.1603/0022-2585-41.6.1082

Talley JL, Wayadande AC, Wasala LP, Gerry AC, Fletcher J, DeSilva U, et al. Association of Escherichia coli O157:H7 with filth flies (Muscidae and Calliphoridae) captured in leafy greens fields and experimental transmission of E. coli $\mathrm{O} 157: \mathrm{H} 7$ to spinach leaves by house flies (Diptera: Muscidae). J Food Prot 2009; 72(7): 1547-1552. PMid:19681284. 